\title{
Relationship between Macroeconomic Indicators and Capital Markets Performance in Selected Southeastern European Countries*
}

\author{
Ante Dodig ${ }^{* *}$
}

\begin{abstract}
This study tests the weak form of the efficient capital markets theorem in five transition economies in Southeast Europe between 2005 and 2016. A panel pooled mean group estimator is used to examine the relationship between macroeconomic indicators and the performance of stock market indexes. This is a suitable estimator for these young frontier markets, given that they have yet to develop the breadth and depth of an advanced market-such as ample liquidity and traders-to aggregate cross-country data and use level series prime data instead of differentials of the same. These frontier capital markets are found to be weak form ineffcient, meaning that stock prices do not reflect available current public information. In other words, when a market is transparent and investor behavior is rational, the macroeconomic data should be included in the value of the stock indexes. The five countries may benefit from bringing their capital markets legislation in line with those of developed countries and by improving corporate governance and transparency. This would boost investor trust and liquidity. The coverage of this research can be extended to find more standardized data values and develop additional factors not captured by this model.
\end{abstract}

Keywords: Economy; Capital Markets; Frontier and Emerging Markets; Southeast Europe; Market Efficiency

JEL Classification: $\mathrm{G} 14, \mathrm{G} 15, \mathrm{C} 33$

\section{Introduction}

Economic stability is vital for a wide set of stakeholders, from investors to taxpayers, researchers, and policymakers. Since the 2007-08 subprime mortgage crisis in the

\footnotetext{
* The paper was originally published in the organization (link <https://openknowledge.worldbank.org/ handle/10986/34169> ): World Bank Policy Research Working Papers.

** Ante Dodig is an Investment Officer at International Finance Corporation - Financial Institutions Group in Europe and Central Asia. E-mail: adodig@ifc.org
} 
United States sparked the Great Recession around the world, authorities have been putting in place new accounting, legislative, and regulatory requirements to shore up their financial systems and support economic recovery and growth. Even so, challenges remain. The global economy suffered a new slowdown in 2020 at a time when people are becoming increasingly attentive to caring for the environment and aware of the importance of economic stability.

This research paper provides critical insight into the relationship between the macroeconomy and capital markets by taking a deep look at how they are interlinked in five transition economies in Southeast Europe: Bosnia and Herzegovina, Croatia, North Macedonia, Serbia, and Slovenia. These markets share several traits. For one thing, all of them were once part of Yugoslavia and are now transitioning from planned to free-market economies. Their financial systems are also bank-centric; they have little activity in their capital markets. Still, each of these countries differs in terms of their model of economic transition, pace of capital markets evolution, and economic structure and development.

The goal of this study is to empirically test the efficient capital markets theorem developed by Eugene Fama and Burton Malkiel (Fama \& Malkiel, 1970) in the five selected economies. The theorem is a measure of the degree to which current market prices reflect available and relevant information. The underlying assumption of the hypothesis is that prices instantaneously reflect the available and relevant public information when full transparency exists and investors behave rationally. In other words, the impact of macroeconomic indicators should be incorporated a priori into stock prices in all forms of capital markets efficiency-weak, semi-strong, and strong. The three levels of capital market efficiency are:

1. The weak form of capital market efficiency means that stock prices today reflect all the data of past stock prices and any available public information. Based on this hypothesis, however, future stock prices are independent of historical public information. That makes technical analysis worthless for investors seeking to make additional gains from their trading decisions.

2. The semi-strong form of capital market efficiency, also known as the event form, is when stock prices adjust rapidly to the release of new public information. As such, technical and fundamental analysis is not worthwhile for investors seeking an opportunity to benefit beyond the market's performance.

3. The strong form of capital market efficiency, or the private-information form, is when private information, or that which is restrained from public access, or what is often called insider information, is fully captured in stock prices. Given that the hypothesis of strong capital market efficiency is a precondition for transaction and information costs to be inexistent, we consider this form to deal with an effective approximation of a perfectly efficient capital market. This market is not empirically researched in this paper. 
The scope of this research is to test the weak form of efficient capital markets in the transition economies in Southeast Europe by examining the relationship between historical macroeconomic indicators and the prices of stocks traded on the regulated exchanges in those countries.

In this paper, a specific model of relationship patterns is observed to show the testing limitations. The limits relate, largely, to the operating environment not having a very long series of data with a good standardized relationship, and in not being able to control all of the external influence factors in policies, institutional capacities, and so on. With the weak form of the efficient market hypothesis, the prices of stocks on regulated exchanges should not be predictable from the publicly available macroeconomic indicators. In the general market equilibrium, under the precondition of fair competition and behavioral homogeneity, future prices follow a "random walk" from the historical prices, meaning that the future prices are independent and not determinable solely from the observation of historical prices. In academic research, the semi-strong (or event) form of capital market efficiency is seldom tested because of the limited access to daily free-float data and the lack of corporate actions to analyze it. The strong form of capital market efficiency is not tested either because of the widely recognized existence of transaction and information costs in the relevant markets that refute the existence of perfectly efficient capital markets.

This research, therefore, aims to test the weak form of the capital market efficiency theorem for the five transition markets in Southeast Europe by examining how a change of macroeconomic indicators in a country passes onto selected stock prices over time and across countries. In addition, in-depth reviews of the capital markets in the selected countries and the surrounding environment are provided. These profiles add relevant scope for the relatively new-and still lackluster-capital markets in Southeast Europe. These markets are an inept form of strong capital market efficiency because of their apparent market transaction and information costs. Without liquid daily trading data, the capital markets in Southeast Europe are also likely to be considered inept when using the semi-strong form of capital market efficiency.

Finally, the empirically confirmed weak form of capital market inefficiency in Southeast Europe would bring up considerations that the capital markets may fail to play a fully functional role in the economies of those countries. Such a failure would be apparent in the lack of price discovery, improved transparency, and, ultimately, in an increase in the liquidity and cost effectiveness of those capital markets to be able to provide financing to the most productive economic sectors. In contrast, developed markets are efficient capital markets. This is clearly evident in the absorption of publicly available macroeconomic information in stock prices.

The results in frontier and emerging markets are not so clear, and that is often because of the specific ineptitudes inherent in the business environment. Recent research on the development of capital markets in Southeast Europe using capitaliza- 
tion and turnover ratios shows that there is a relationship between structural and macroeconomic indicators and the fluctuations in gross domestic product (GDP) (Fink, Haiss, \& Vuksic, 2005; Lazarov, Miteva-Kacarski, \& Nikoloski, 2016; Drazenovic \& Kusanovic, 2016). A number of comparative studies also consider capital market efficiency by using bivariate tests on the relationship between macroeconomic indicators and the performance of stock market indexes in Slovenia and Croatia (Barbic \& Condic-Jurkic, 2011). This research complements that study with extensive and approximated full-economic cycle data, as well as with more reliable multivariate and panel study tests. A number of researchers have proven that the relationship between macroeconomic indicators and capital markets increases with the length of time that it is under study (Fama, 1990; Binswanger, 1999).

Price variations in capital markets over time are common and related, in plausible ways, to overarching market conditions that incorporate research samples in a specific economic environment. In recognizing the existence of anomalies in the markets of Southeast Europe, this paper investigates the surrounding conditions under which the implicit empirical statistical tests are conducted.

In these selected capital markets, liquidity and intermediation are low, and infrastructure is subpar. The information asymmetries also overshadow the credibility of the operations. In general, these markets play a nonsignificant role in the local financial systems and economies. They do not efficiently protect minority ownership rights. Neither do they have the best standards in corporate governance, nor the sustainable liquidity for efficient price discovery and cost-effective savings and investments solutions. These conditions are largely attributable to the transition from planned to free-market economies, a process that early on included a rush to establish stock exchanges as vehicles for the privatization of state assets.

The results of this empirical research show that the capital markets in these Southeastern European countries are weak form inefficient. However, past results are not an exclusive indicator of future performance and should be viewed in the context of the operating environment in these markets. The relatively short history of the capital markets in these countries means that the availability of extensive and standardized data is limited. Empirical testing shows that there is a relationship of macroeconomic factors on stock prices, highlighting market inefficiency in the observed research environment.

This research seeks to raise awareness and build knowledge about the characteristics, opportunities, and risks of the diversified financial systems being adapted in the selected capital markets of Southeast Europe. To help foster innovative financial products, this research seeks to add more context and provide empirical evidence that will provoke thought on how an economy with a small capital market can be competitive against market Goliaths, and what market failures can be considered to be necessarily hereditary to developing markets. When there are overextended moves in frenzied times in established electronic capital markets (Kleinman, 2013), a small nascent capital market may be naturally hedged and thus serve as a global example of 
a better balance in joint work between electronic- and human-led professional players in the market.

An opportunity for improvement in the operations of these capital markets may very well lie in strengthening the standards of transparency and corporate governance. An example of what to do is to harmonize legislative and regulatory standards with effective enforcement. Further upside can come from integrating the selected markets to improve operating efficiencies and provide the scalable exposure and internationalization that can broaden and deepen the base of investors in each of the markets.

There may also be an opportunity to increase liquidity by reorganizing nonperforming assets, such as corporate debt that has suffered from an economic slowdown or financial crisis, under a structure that makes it possible to find a resolution for these assets. Additional liquirity may come by transforming closed privatization funds to open-end ones, for example, or by building on the trend of issuing and trading debt instruments through the introduction of structural products such as mortgages and other asset-backed securities. With these improvements, political support for structural and policy changes likely will follow in the medium term, making it possible to incorporate more local insurance and pension funds-and other institutional investors - into the capital markets, and to complete the planned privatizations of the systemic players already listed on stock exchanges. This will pave the way for the creation of a regional and centralized counterparty for contracts enforcement, helping to increase the safety of the inherent capital markets.

Table 1: SEE countries financial system and capital markets preview.

\begin{tabular}{|c|c|c|c|c|c|c|}
\hline $\begin{array}{c}\text { Year-end } 2016 \text { Estimates (current } \\
\text { prices) }\end{array}$ & Croatia & Serbia & $B \& H$ & Slovenia & $\begin{array}{c}\text { North } \\
\text { Macedonia }\end{array}$ & $\begin{array}{c}\text { World } \\
\text { (Southeast } \\
\text { Europe \%)* }\end{array}$ \\
\hline GDP (US\$ billion $)$ & 48.6 & 36 & 15.9 & 42.7 & 10.9 & $\begin{array}{l}75,600 \\
(0.2 \%)\end{array}$ \\
\hline Financial assets (US\$ billion) & 81.4 & 31.7 & 14.8 & 55 & 9 & $\begin{array}{r}300,000 \\
(0.06 \%) \\
\end{array}$ \\
\hline $\begin{array}{l}\text { Regulated stock market capitalization } \\
\text { (US\$ billion) }\end{array}$ & 32.4 & 2.7 & 5.6 & 5.3 & 2.1 & $\begin{array}{r}60,000 \\
(0.08 \%)\end{array}$ \\
\hline $\begin{array}{l}\text { Stock market turnover ratio \% (annual } \\
\text { regulated trade / regulated market } \\
\text { capitalization) }\end{array}$ & 1.7 & 13.5 & 2.1 & 6.7 & 2.2 & 40 \\
\hline $\begin{array}{l}\text { Over the counter (OTC) (US\$ billion): } \\
1 \text { - OTC markets turnover } \\
2 \text { - Financial derivatives: } \\
\text { a) Notional contracts value } \\
\text { b) Open interest value }\end{array}$ & $\begin{array}{r}N A \\
N A\end{array}$ & $\begin{array}{r}28.1 * * ; \\
N A ; \\
N A\end{array}$ & $\begin{array}{l}N A ; \\
N A ; \\
N A\end{array}$ & $\begin{array}{r}3.2 ; \\
N A ; \\
N A \\
\end{array}$ & $\begin{array}{r}2.1 ; \\
N A ; \\
N A \\
\end{array}$ & $\begin{array}{r}N A ; \\
544,000 ; \\
86,000 \\
\end{array}$ \\
\hline
\end{tabular}

Note: Data sources are available in Appendix 3 - Data sources, limitations, and descriptive statistics. NA indicates that the data is not available and OTC indicates the over the counter, non-exchange traded market.

* Aggregate of Southeastern European countries under research as a share of the world aggregate.

$* * 95 \%$ of recorded OTC transactions involves central bank repos that are not reported for other research countries. 
This paper is organized into five sections. The first is an introduction to the background environment and the economic thought behind the research question. The second section is a review of the literature behind the study. In the third, the empirical assessment method is designated. The fourth section describes the empirical results and implicit interpretations, while the conclusion rounds out the findings.

\section{Literature review}

The relationship between the financial system and economic performance has long caught the attention of academics, investors, and policymakers. The result is a large body of literature that provides evidence on how macroeconomic fundamentals and financial markets are connected. Most of it, however, is focused on advanced countries. There is little research on this relationship in emerging markets, less so for the frontier capital markets of Southeast Europe. And the research that is available has widely differing results. This is mostly because the capital markets in Southeast Europe are relatively young, meaning that there is little data to show the correlation between economic and stock performance. This has created methodological inconsistencies and deterred research.

For countries, empirical research on the impact of macroeconomic indicators on financial markets can foster growth in economic output by showing how it improves savings, liquidity, purchasing power, and management effectiveness. Initially, the relationship between aggregate economic output and the intermediary role of the banking sector in the frontier financial industry was a target of researchers. Over time, however, attention has shifted to the relationship of economic output with what has become a dominant financial industry, namely the capital markets. Initial research on the capital markets looked at the level of development as approximated through market size and turnover, but attention was later put on the macroeconomic relationship with stock prices.

Under the weak form of the efficient capital markets theorem, researchers at first considered the impact of macroeconomic indicators on the prices of exchange-traded stocks (Megaravalli \& Sampagnaro, 2018; Lee \& Wang, 2015; Pilinkus, 2010), but a few other researchers tested for the existence of a causal influence of macroeconomic indexes on stock prices (Plihal, 2016). Researchers have also looked at how to explain market anomalies by conducting volatility tests, such as seasonality or a disproportionate frequency of stock returns (Flannery \& Protopapadakis, 2002).

The views of economists and the results of diverse empirical research differ on the relationship between the financial system and aggregate economic output growth, yet a sense that there is a positive impact prevails for developed markets (Fama E. F., 1981; Chen, Roll, \& Ross, 1986; Dumas, Campbell, \& Ruiz, 2003). Studies conducted 
on the association of the impact of macroeconomic indicators on capital markets normally follow the theorem that economic activity should a priori be reflected in stock prices and ever more consistently in the long run (Fama E. F., 1990; Shapiro, 1988). Empirical research, however, shows that the rational expectations for the relationship are empirically justifiable, but that bubbles and trends exist in the relationship (Binswanger, 1999; Domian \& Louton, 1997; Issahaku, Ustarz, \& Domanban, 2013; Erhmann \& Fratzscher, 2004) and that stock prices correlate more in poor economies as a result of the large public sector and the systemic- versus firm-specific component in performance (Morck, Yeung, \& Yu, 2000). More obscurity appears in emerging markets: the results are often assigned to specific constraints related in the inefficiencies of transition economies (Naceur, Ghazouani, \& Omran, 2007; Koivu, 2002; Fink, Haiss, \& Vuksic, 2005; Cojocaru, Falaris, Hoffman, \& Miller, 2015).

Altogether, the studies on the relationship between macroeconomic indicators and the prices of exchange-traded stocks in emerging markets are relatively scarce and inconclusive. Repeat studies are required using a more extensive set of data, more mature and standardized performance, and better statistical methodologies.

Researching the relationship dynamics between macroeconomic fundamentals and the performance of stock exchanges in the selected Southeastern European countries makes it possible to do a comparative study with past research in other emerging and advanced economies. These include the nexus of capital market development to economic growth (Fink, Haiss, \& Vuksic, 2005; Lazarov, Miteva-Kacarski, \& Nikoloski, 2016; Drazenovic \& Kusanovic, 2016) and the connection of the impact of macroeconomic indicators on prices in capital markets (Barbic \& Condic-Jurkic, 2011; Megaravalli \& Sampagnaro, 2018; Lee \& Wang, 2015).

In testing for the existence of the weak form of capital market efficiency in the selected Southeastern Europe countries, this research provides the first multivariate model test on statistically significant cointegrating relationships. The results prove the inefficiency of the markets with respect to an apparent nonexistence of an a priori inclusion of macroeconomic information in available stock prices. This is a first-ever study of the significance of the dynamic relationship and directional impact of macroeconomic indicators on regulated stock market prices in Bosnia and Herzegovina, North Macedonia, and Serbia. For Croatia and Slovenia, this research makes advances on the multivariate model test and dynamic panel testing methodology. Finally, this research introduces for the first time the use of new indicators such as GDP per capita, the industrial production index, the exchange rate, and the balance of payments net financial account (BOPNFA) in the inherent research markets. This is the most recent and extensive research on this subject, improving the robustness of the model with further data and with more standardized performance in the later life of what otherwise are still considered frontier capital markets. 


\section{Empirical Approach Using the Pooled Mean Group Method and Data Sources}

There is evidence that links the performance of macroeconomic variables on the prices of exchange-traded assets using different methodological specifications. These include: 1) the theoretical capital asset pricing model (CAPM), the international CAPM that includes foreign exchange risk as well, the arbitrage pricing theory (APT), and the present value model (PVM) for valuations; 2) modeling in using data regression in vector autoregression (VAR), the vector error correction model (VECM) cointegration test, ordinary least squares (OLS), the pooled mean group (PMG), fixed effects, and random effects estimations; 3) testing for the relationship existence and spurious causality in the Johansen long-run cointegration test, the Granger short-term relationship causality; and 4) the autoregressive integrated moving average (ARIMA) and the general autoregressive conditional heteroskedasticity $(\mathrm{GARCH})$ for conditional volatility in second level residuals and frequently testing for the impact of corporate actions on daily price data on liquid stocks.

This empirical testing uses advancements in the statistical methodologies with multivariate panel PMG, which increases the reliability of the results through the reduction of biases (Megaravalli \& Sampagnaro, 2018). The frontier capital markets in Southeast Europe have only a small sample of data, which hampers testing. To resolve this, this research uses panel analysis to broaden the data set. Panel analyses allow for the use of cross-border data pooling. In addition, panel PMG analysis provides a better result for collinearity through the use of more degrees of freedom. Panel PMG resolves the static model inconsistencies present in fixed effects (FE), random effects (RE), generalized method of moments (GMM), and mean group estimators. The PMG technique deals with the dual benefit of resolving the issues of country bias by fixing the panel long-run coefficients. It also allows variability on the short-run slope on aggregate and individual country data, and on intercept for the data on each country. It then captures further variability and does a better job of resolving a bias of unobserved error. As a result, the PMG method can simultaneously incorporate cross-sectional information and tolerate data heterogeneity.

The PMG method is particularly conducive to this empirical study because of the traits of the Southeastern European markets in which long-run fixed coefficients capture the shared characteristics in the legacy and the new mutual infrastructure. This includes ethnic, cultural, and language similarities, the recognition of commercial brands, a common path toward single market and European Union membership, and the prime trade relationships with each other. Even so, the shortrun heterogeneities are also captured in reflecting the varying degrees of the state of economic development in single countries, where Croatia and Slovenia lead the way as high-income countries with economic structures made up of varying sectors and prevalence, and ultimately, in the development of their capital markets by innovation or sheer size. 
Lastly, PMG is the preferred method because of the underlying characteristics of the data given that PMG uses level series prime data. The panel PMG estimator has the capacity to treat both stationary and non-stationary data, something that is limited in most other methodologies. This makes it possible to use the largest type of informational content: level series data. Any process of data transformation comes with lesser precision as a result of the removal of identifying variance in precedent level dimensions. In this study, the available data are in their entirety only stationary in the second-degree level of transformation, which limits the informational value for those alternative test methods. An example is the Granger test, which requires data stationarity as a precondition.

This research differs from the previous studies in Southeast Europe by applying for the first time the panel PMG multivariate relationship model to study an impact by environment-relevant macroeconomic indicators on the performance of inherent stock exchange indexes. In PMG method testing, the error correction mechanism is used because it is a way to estimate how a deviation from a long-run equilibrium influences the dynamics of the short-run-and the speed of the adjustment. As part of this mechanism, the error correction term (ECT) in its statistical significance confirms a stable long-run relationship. The more negative ECT sign illustrates a stronger relative speed of return to the equilibrium relationship in a single quarter period of time on the short-run impact of macroeconomic indicators on stock prices. This paper utilizes the PMG estimation developed by Pesaran, Shin, and Smith (1999). The advantage of the PMG method is the flexibility to allow short-run coefficients to be heterogeneous across the data of different countries while constraining the long-run slope coefficients so that they are homogeneous across the coherent data of the countries. At the same time, PMG allows differences as diverse intercepts and error variances, providing further estimation efficiencies and consistencies in the results. This research applies the Hausman test to distinguish significant differences and preferences among the frequent dynamic model estimators of PMG, MG, and dynamic fixed effects.

Dynamic model estimators are preferred to the static models of RE and FE because the sample data and model specifics of testing the long-run relationship and adjustments to the long-run equilibrium. The techniques of static models result in inconsistencies when dealing with small sample sizes and non-stationary data. If the Hausman test results point to a p-value larger than 5 percent, then the PMG model is preferred to the MG model. The reason for choosing PMG over FE is the flexibility of the dynamic time-interval relationship analysis in allowing short-run coefficients heterogeneity across groups while still efficiently capturing the characteristics of long-run shared group factors.

The PMG model can incorporate cross-sectional information and tolerate data heterogeneity, and thus it is conducive to this empirical study with the shared traits of the markets in Southeast Europe and their distinctive traits as individual coun- 
tries. First, the existence of a stable long-run cointegrating relationship among the variables of interest requires that the coefficient on the ECT be negative and not lower than negative two. Statistically significant ECT states that the deviation from the long-run associating equilibrium model relationship, under impact of macroeconomic indicators on a stock market index (SMI) in the short run, is then adjusted quarterly until returning to the long-run equilibrium relationship, all other things being equal. Otherwise, the existence of a relationship would be spurious and no meaningful interpretation would exist on the statistical model results. Second, an important assumption for the consistency of the autoregressive distributed lag model (ARDL) is that the resulting residual of the error-correction is serially uncorrelated and that the explanatory variables can be treated as exogenous. Such conditions can be fulfilled by including the ARDL (p,q) lags for the dependent (p) and independent variables (q) in the error-correction form. Third, the relative size of time-series (T) and sample size $(\mathrm{N})$ is important because the use of the dynamic panel technique helps avoid biases in the average estimators by resolving the issue of heterogeneity. Through this estimation approach, the multiplicity between macroeconomic variables - the BOPNFA, in the (1) formula below-and stock indexes can be presented while solving for the traditional panel model association problem. This research utilizes the following panel PMG model:

$S M I=\mu_{i t}+\lambda_{i} S_{I_{t-n}}+\beta_{t}$ GDPPC $_{i t-n}+\beta_{t} F X_{i t-n}+\beta_{t}$ MMIR $_{i t-n}+$
$+\beta_{t} \operatorname{HICP}_{i t-n}+\beta_{t} I^{P I} I_{i t-n}+\beta_{t}$ BOPNFA $_{i t-n}+\varepsilon_{i t}$

In the (1) formula above, $\beta$ term is the long-run parameter coefficient, $\lambda$ is scalar value vector, $i$ represents countries, $t$ refers to time, $\mu$ refers to the constant value, $n$ represents time periods, and $\varepsilon$ refers to error disturbances. An optimal number of time lags was determined by the results guidance of Schwarz Bayesian information criterion (SBIC). This research paper introduces, for the first time, coverage of the model relationship between the selected set of macroeconomic indicators and the level of stock exchange indexes (SMI). The selected macroeconomic indicators include gross domestic product per capita (GDPPC) in euros, inflation (HICP) in nominal value, the levels of industrial production (IPI) indexes, the local currency exchange rate (FX) with the United States dollar (US\$) in nominal value, the money market interest rate (MMIR) in nominal value, and the balance of payments net financial account (BOPNFA) in euros. The proxy for the regulated exchange-traded stock prices in Bosnian and Herzegovinian (B\&H), Serbia, North Macedonia, Croatia, and Slovenia are the respective equity indexes: BATX, BELEX15, MBI10, CROBEX, and SBITOP. This research tracks quarterly data in an approximate full economic cycle of 11 years starting from year-end 2005, capturing the peak valuations in 2007, the ensuing recession, the ongoing recovery, the kick-start of growth, and an already apparent slowdown. 
The capital markets in Southeast Asia are classified as frontier, which means that the availability of data is very limited. This paper uses end-of-quarter data for the calendar year, with the initial quarter starting on December 31, 2005 and the data set ending on December 31, 2016. In this sense, the study uses data with a starting point ex post to the establishment of the frontier capital markets and initial transitional years, which were marked by frequent transaction failures. More so, the study captures approximate data for the full economic cycle, thus lowering the seasonality bias in the results. The data is sourced from Bloomberg, Eurostat, the European Commission Directorate-General for harmonized data, and the central banks and national statistics agencies in the countries under study.

In this empirical research, the model variables are chosen by the common times series variables included in the studies of capital markets performance, the popularity and frequency in research, the state of the underlying Southeastern European economies, and the pervasiveness of the indicators. The other factors of choice are the simplicity in accounting and the availability of the data. Given that prices in capital markets are influenced by company-specific, industry-specific, and external sociopolitical impacts that are not controlled for in this paper, the focus of this research is to measure, ceteris paribus, the implied relationship with the selected macroeconomic indicators. This research addresses the limitation of the omitted variables error by broadening the sample data set in conducting a cross-country panel study and utilizing the advancements in the PMG methodology, which have improved the reliability of results. The dependent variables that were chosen are the end-of-quarter values of the individual stock exchange indexes. The independent variables, on the other hand, are the end-of-quarter values of a set of chosen macroeconomic indicators.

Among the chosen independent variables, the economic rationale establishes that countries with higher GDP per capita tend to simultaneously have more developed capital markets, which in turn have larger capitalizations and more liquidity. As a result, these more developed markets tend to show less of a correlation with stock price movements (Morck, Yeung, \& Yu, 2000).

In further theoretical and empirical rationale, stock prices commonly respond negatively to the actual unexpected inflation rate. This rate directly and negatively impacts purchasing power, while in parallel negatively and indirectly increases the impact effect through a greater sentiment of investor uncertainty. The United States Federal Reserve System (Fed) theory presumes that higher inflation increases yields on bonds. Higher-yield bonds, in theory, compete directly with equity for investor interest and demand, and thus capital flows from stocks to debt securities at such times. Hence, higher inflation is expected to lower stock prices.

An increase in industrial production indicates greater activity in capital markets through the direct effect of better financial performance by listed companies, or through the indirect effect contribution of greater disposable income for purchases 
in the market (and vice versa). The result: greater industrial production theoretically implies stronger stock prices.

In the theoretical rational, the comparative value in the local currency indicates the competitiveness of the domestic economy and domestic companies in international markets. In addition, when determining the risk of currency fluctuations on the level of macroeconomic stability, foreign investors consider not just the current exchange rate, but also its change in value and the risk of regulatory control on capital flows. A decrease in the value of a local currency is expected to imminently and negatively affect investor returns and their determination in both equity and debt, thus reducing the performance of capital markets (and vice versa) under the portfolio balance perspective. Even so, under the flow-oriented theory, export-based companies benefit in competitiveness and performance in the longer run, and these companies then go on to become key drivers of an improvement in the performance of capital markets.

Lower money market interest rates boost liquidity in the market and, hence, a higher flow of funds to investments. In the flow-on effect, higher investments increase activity and performance in the real sector, which is then reflected in an improvement in stock prices. Before that, lower money market rates create a disincentive to invest in debt securities, spurring a rebalancing of investment portfolio positions because of the inherent valuation change, which, all things being equal, contributes to an immediate rebalancing in favor of new funds investing in equity instead of debt securities.

The balance of payments net financial account (BOPNFA) indicator tracks broad implied economic activity under net acquisition and the disposal of financial assets and liabilities. This indicator tracks how net lending to-or borrowing from-nonresidents is financed. Alfaro, Chanda, Kalemli-Ozcan, and Sayek (2004) proved that more developed financial markets absorb capital more effectively than less developed markets. In the economic structure of Southeastern European countries, foreign direct investments (FDIs), remittances, international borrowings, and national reserves form material economic constituents. In this empirical testing, we seek to track the broad statistical relevance in the indicator movement on the performance of capital markets.

\section{Empirical results and sensitivity analyses}

This paper uses a panel PMG pooling of a wide range of data from the capital markets and macroeconomies in Southeast Europe to test for inherent relationship dynamics in the short and long run. It also uses the panel PMG estimation efficacies of fixing longrun coefficients for more reliable group data results on the existence of a relationship over the short and long run. In addition, this research utilizes further PMG estimation efficacies in allowing the intercept of short-run associating relationships as well as error-variance variability on the individual country basis, making it possible to enable sensitivity testing on short-run results dynamics for each individual country. 
Table 2: PMG Test Results - Group Score

\begin{tabular}{|l|c|c|}
\hline Variable: & Coefficient & Standard Error \\
\hline Long run: & -2.2986 & 1.972 \\
\hline GDPPC & 129.4836 & 1483.247 \\
\hline FX & $-77039.64^{* *}$ & 30387.31 \\
\hline MMIR & $-418.4206^{*}$ & 113.3164 \\
\hline HICP & 12.235 & 11.4485 \\
\hline IPI & $3.0562^{*}$ & 1.0272 \\
\hline BOPNFA & $-0.088[0.075]^{* * *}$ & 0.0494 \\
\hline ECT*** & -0.4891 & 23138.24 \\
\hline Short run: & 36805.34 & 2556.772 \\
\hline GDPPC & 3245.045 & 31.0176 \\
\hline FX & 27.4077 & 3.1278 \\
\hline MMIR & 3.2396 & 0.1052 \\
\hline HICP & 0.0083 & 2549.367 \\
\hline IPI & $4653.075^{* * *}$ \\
\hline BOPNFA & \multicolumn{2}{|c|}{3.1480 .709} \\
\hline Constant & $0.4213]$ \\
\hline \multicolumn{3}{|c|}{} \\
\hline Log likelihood & \multicolumn{2}{|c|}{} \\
\hline Hausman test & $\begin{array}{l}\text { The Hausman test indicates PMG consistency with } p \text {-value }>5 \text { percent, thus illustrating non-significance to } \\
\text { reject a null hypothesis of systemic difference in coefficients. From thereon, PMG long-run coefficients fixing } \\
\text { prevails as the choice of method. } \\
\text { The log-likelihood value determines the plausibility function of the model under the observed data. }\end{array}$ \\
\hline
\end{tabular}

Note: The optimal selection order criteria is determined by Schwarz Bayesian information criterion ("SBIC"). ARDL $(4,4)$ and data interval 2006Q1-2016Q1 is chosen. [] is p-value.

* Null hypothesis is rejected at 1 percent level.

** Null hypothesis is rejected at 5 percent level.

*** Null hypothesis is rejected at 10 percent level.

$* * * *$ Error correction term.

In the results of the sample data panel PMG test for the aggregate Southeastern European group the relationship between macroeconomic indicators and stock prices is statistically significant, with the error correction term (ECT) being negative and statistically significant at the 90 percent confidence interval. The results suggest a stable long-run relationship and infer that capital markets are weak form inefficient because of the evident empirical impact of the value of the macroeconomic indicators on the value of the stock indexes. In the results, the macroeconomic indicators are estimated to have an impact of an around 8.8 percent short-run deviation in one calendar-year quarter from the long-run equilibrium value of the stock index. The deviating impact is then adjusted until the long-run model relationship equilibrium 
level is reached. The existence of the ECT is in line with the expected equilibrium behavior as individual countries take control actions, which then brings about the error correction mechanism. These control actions may be in the form of policy reactions, such as changes in the benchmark interest rate, the tax policy on capital gains, or other legislative reactions, regulatory changes, or other similar actions. The cases where the impact of the long-run estimating coefficient is stronger than the impact of the short-run equivalent may signify deeper, market-specific, and underlying structural asymmetries and the inherent irrational behavior of investors. In such a situation, an anomaly environment is apparent in which the market is further considered inefficient in the long run when the results are standardized to exclude one-off or seasonal effects. Cases of the significance of the short-run relationship without the existence of a long-run stable relationship do not infer any meaningful interpretable results. Both the cases of a short-, under-stable, and long-run relationship and a sole long-run statistically significant impact empirically confirm the existence of the weak form inefficiency of capital markets. In efficient markets, the model relationships would otherwise be insignificant.

In the long-run relationship, the estimation coefficients of the HICP, MMIR, and BOPNFA indicators are statistically significant, while the impact caused by other macroeconomic indicators is statistically nonsignificant. The MMIR and HICP indicators show a negative slope of the long-run relationship estimating association, while the BOPNFA estimating association indicator is positive with the SMI. In the short run, the results indicate that all the slope coefficients of the macroeconomic indicators are statistically nonsignificant, but persistence in the model relationship existence, through constant value, remains significant.

The results of this research are sample-data specific. That's in part because of the structure of the selected capital markets, which are concentrated in a small number of large corporates and have few portfolio investors and traders of fixed-income securities who frequently are more sensitive to interest rates changes (Erhmann \& Fratzscher, 2004). In comparable research by Megaravalli and Sampagnaro (2018), a statistically nonsignificant impact from inflation was found as well as a statistically significant positive impact in the long run from the FX factor on the stock indexes of three Asian countries in the study period from 2008 to 2016, but not in the short run.

While our results also point to non-significance in short-run relationships, in the long run the HICP indicator has a statisticially significant coefficient showing a negative relationship with the SMI. The direction of this relationship is in line with the Fed theory, which presumes that higher inflation increases yields on bonds that, in theory, compete directly with equity for the interest of investors. However, the structural review shows a lower prevalence of fixed-income securities traders in the markets of Southeast Europe. Nevertheless, in the valuation theory, the impact of unexpected inflation on interest rates decreases the present value of equity. Inflation is expected to deter activity in capital markets as a signal of contemporaneous changes 
and a future increase in inflation, which may negatively impact the dynamism of financial intermediation in the market and in aggregate economic output (Azar, 2010; Balduzzi, 1994; Campbell \& Vuolteenaho, 2004).

In other comparative findings, Issahaku, Ustarz, \& Domanban (2013) used the VECM test on monthly data during the study period of 1995 to 2010 . The results show that inflation and FDI had a statistically significant positive impact on the performance of the Ghanaian stock exchange, while money supply had a negative impact.

In this research, the results of the empirical testing also show that an increase in the money market interest rate (MMIR) provides a negative association relationship for the estimating coefficient on the SMI in the long run, which is in line with the portfolio theory that a contracting monetary policy will yield a shift in portfolio preference from equity to fixed-income assets. The implications from the direction of relationship with the MMIR factor is in line with common research findings that higher returns come when monetary policy is more expansive (Johnson, Jensen, \& Conover, 1999; Erhmann \& Fratzscher, 2004). Even so, Pilinkus (2010) shows a positive money supply estimating association with the stock exchange index in his study in the case of Estonia during the study period of 2000 to 2008.

The findings of the empirical testing of a statistically significant BOPNFA relationship estimating coefficient in this research is in line with former findings on the explanatory relationship significance of FDIs and international reserves on stock prices (Barbic \& Condic-Jurkic, 2011; Issahaku, Ustarz, \& Domanban, 2013) or on the growth of economic output (Lazarov, Miteva-Kacarski, \& Nikoloski, 2016; Lee $\&$ Chang, 2009). Be that as it may, the BOPNFA research indicator also captures the interactions of financial assets, portfolio investments, reserve assets, and debt investments, and thus provides for a broader joint factor impact on stock prices. So, while the results show a positive BOPNFA coefficient, the findings in this research are limited in the direction of the relationship of the results because the sub-component source of the associating relationship was not analyzed. Rather, the results are limited to the existence of a statistically significant relationship between the BOPNFA and SMI.

The empirical testing in this research shows non-significance in the relationship with the FX indicator. On the contrary, a panel study of 29 countries in the research period of 2000 to 2011 by Lee and Wang (2015) shows negative in the short run but positive in the long run in the statistically significant estimating relationship association of FX on stock indexes. Also contrary to the results of this empirical research, Alrub, Tursoy, and Rjoub (2016) found a positive long-run estimating relationship association of the industrial production index in Turkey on the Istanbul Stock Exchange in the study period of 2002 to 2013.

The results of this study's empirical research on the non-significance of the GDP$\mathrm{PC}$ indicator are in line with former related research in Southeastern European coun- 
tries (Fink, Haiss \& Vukcic, 2005; Lazarov, Miteva-Kacarski \& Nikoloski, 2016). The non-significance of FX and IPI indicators might represent specifics in the market structure, alluding to the lower importance of the domestic industrial sector on the stock exchanges and less of a prevalent presence of more FX sensitive portfolio investors seeking to rebalance the investment positions of their portfolios.

Table 3: PMG Test Results - The Cluster Scores of the Individual Countries in Southeast Europe

\begin{tabular}{|c|c|c|c|c|c|c|c|c|c|c|}
\hline \multirow{2}{*}{ 恶 } & \multicolumn{2}{|l|}{ 卺 } & \multicolumn{2}{|l|}{ 覀 } & \multicolumn{2}{|c|}{ 妾 } & \multicolumn{2}{|c|}{ 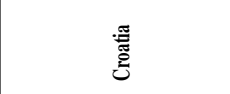 } & \multicolumn{2}{|l|}{$\begin{array}{l}\text { 套 } \\
\text { 言 }\end{array}$} \\
\hline & $\begin{array}{l}\text { Coef. } \\
* * * * *\end{array}$ & $\begin{array}{l}\text { St.Er } \\
* * * * *\end{array}$ & $\begin{array}{l}\text { Coef. } \\
* * * * *\end{array}$ & $\begin{array}{l}\text { St.Er } \\
\text { ******* }\end{array}$ & $\begin{array}{l}\text { Coef. } \\
* * * * *\end{array}$ & $\begin{array}{l}\text { St.Er } \\
* * * * *\end{array}$ & $\begin{array}{l}\text { Coef. } \\
* * * * * *\end{array}$ & $\begin{array}{l}\text { St.Er } \\
* * * * * *\end{array}$ & $\begin{array}{l}\text { Coef. } \\
* * * * *\end{array}$ & $\begin{array}{l}\text { St.Er } \\
* * * * *\end{array}$ \\
\hline \multicolumn{11}{|l|}{ Long run: } \\
\hline GDPPC & -2.2986 & 1.972 & -2.2986 & 1.972 & -2.2986 & 1.972 & -2.2986 & 1.972 & -2.2986 & 1.972 \\
\hline$F X$ & 129.4836 & 1483.247 & 129.4836 & 1483.247 & 129.4836 & 1483.247 & 129.4836 & 1483.247 & 129.4836 & 1483.247 \\
\hline MMIR & -77039.64 * & 30387.31 & -77039.64 * & 30387.31 & $-77039.64 * *$ & 30387.31 & $-77039.64 * *$ & 30387.31 & $-77039.64 * *$ & 30387.31 \\
\hline HICP & $-418.4206^{*}$ & 113.3164 & $-418.4206 *$ & 113.3164 & $-418.4206^{*}$ & 113.3164 & $-418.4206^{*}$ & 113.3164 & $-418.4206^{*}$ & 113.3164 \\
\hline IPI & 12.235 & 41.4485 & 12.235 & 41.4485 & 12.235 & 41.4485 & 12.235 & 41.4485 & 12.235 & 41.4485 \\
\hline BOPNFA & $3.0562^{*}$ & 1.0272 & $3.0562^{*}$ & 1.0272 & $3.0562^{*}$ & 1.0272 & $3.0562^{*}$ & 1.0272 & $3.0562^{*}$ & 1.0272 \\
\hline$E C T^{* * * * *}$ & $-0.0032[0.152]$ & 0.0022 & $-0.0047[0.444]$ & 0.0061 & $-0.2708[0]^{*}$ & 0.0729 & $-0.0787[0.006]^{*}$ & 0.0286 & $-0.089[0.006]^{*}$ & 0.0326 \\
\hline \multicolumn{11}{|l|}{ Short run: } \\
\hline GDPPC & -0.1805 & 0.124 & $00.6208^{*} * * *$ & 0.3532 & -2.7007 & 2.2755 & -0.3946 & 0.4326 & 0.2095 & 0.1399 \\
\hline$F X$ & 249.5239 & 335.5214 & 43076.53 & 41716.68 & 123859.9 & 123730 & $16846.59^{*}$ & 6053.735 & -5.8329 & 269.2273 \\
\hline MMIR & 2078.5239 & 2669.836 & $-3219.989 * * *$ & 1857.111 & 12153.33 & 15678.54 & 681.8826 & 5148.88 & 4531.887 & 9802.912 \\
\hline HICP & $-1.7392 *$ & 0.6595 & $-46.9989 * * *$ & 27.4257 & 16.6579 & 98.4876 & $140.2717^{* *}$ & 63.2239 & 28.8468 & 36.9282 \\
\hline IPI & -0.3925 & 0.623 & -1.3669 & 7.2196 & 15.4785 & 16.857 & 2.5539 & 9.5822 & -0.075 & 3.9573 \\
\hline BOPNFA & 0.0589 & 0.05 & -0.1089 & 0.1757 & 0.3791 & 0.6451 & -0.0404 & 0.0732 & $0.2473^{*}$ & 0.0798 \\
\hline Constant & -146.2289 & 93.1767 & 323.854 & 341.8748 & $14038.3^{*}$ & 3757.012 & $4308.254^{*}$ & 963.9494 & $4746.2^{*}$ & 1001.001 \\
\hline Log likelihood & \multicolumn{10}{|l|}{-1480.709} \\
\hline Hausman test & \multicolumn{10}{|l|}{$3.13[0.4213]$} \\
\hline
\end{tabular}

Note: The optimal selection order criteria is determined by the Schwarz Bayesian information criterion (SBIC). ARDL $(4,4)$ and data interval 2006Q1-2016Q1 is chosen; [] is p-value.

* Null hypothesis is rejected at 1 percent level.

** Null hypothesis is rejected at 5 percent level.

*** Null hypothesis is rejected at 10 percent level.

$* * * *$ Error correction term, coefficient, and standard error.

To closely analyze the results of individual countries, this research utilizes panel PMG quality to allow heterogeneity and cross-countries differing in short-run coefficients in the model regressions, thus enabling dynamism to analyze the relationships 
of the individual countries in the short run. This study's test results show statistical significance in the model relationships for each individual country and then confirm the weak form of the capital market's inefficiency to a priori absorb publicly available macroeconomic information.

In the model relationship analyses of the individual countries the results of this study's empirical testing illustrate the first cases of ECT non-significance. ECT is significant in the cases in Croatia, North Macedonia, and Slovenia, but nonsignificant in the cases in B\&H and Serbia. The short-run relationship may divert from the long-run equilibrium as a result of the seasonality effect, such as an economic boom or bust. But these effects, which are normally temporary, as explained by the short-run dynamic result, will eventually return to the long-run equilibrium. When the long-run equilibrium does not exist, there is no theoretical information that can be extracted from the analysis. Statistically significant ECT results suggest a stable long-run cointegrating relationship between macroeconomic indicators and stock indexes. In these stable relationships, the short-run deviation apparent for estimating the impact of the macroeconomic indicators is adjusted for by the return to a long-run equilibrium relationship. The ECT adjustment coefficient is most prominent in North Macedonia, then in Slovenia, and Croatia after that. ECT for the case of B\&H would be significant under the 85 percent confidence interval, and the ECT coefficient for the case of Serbia would only be significant in a 55 percent confidence interval. In the cases of B\&H and Serbia, the research results imply that the short-run estimating relationship impact by macroeconomic indicators causes an increasing long-run relationship deviation from the equilibrium relationship balance with the respective stock index value.

In the prominent individual countries, the estimating coefficients of the short-run statistically significant macroeconomic indicators are largely specific to the individual markets and have unique short-run horizons. The estimation inefficiencies biases are more likely in the sub-set group tests because of a smaller set of data, which means that there is a lower degree of the shared integrated economic factor in the data set-and in the overall variability of the data. Such results, in particular for the short-run relationships, are not erroneous. Rather, they are caused by differences in the specific integrated information asymmetries of the sample data.

When looking at the stable long-run relationship models, the results of the individual case of North Macedonia replicate the data for Southeast Europe as a whole set of data, showing no significant macreoeconomic indicators in the short-run relationship. But it still has persistence in the relationship model, as apparent through the significant constant term.

This study's empirical test results for the individual case of Slovenia differ from North Macedonia in the significance of the BOPNFA indicator, which, in the case of Slovenia, is through the positive association coefficient in the relationship. While not tracked factually and not endogenized in the testing model, international fund flows 
in this research environment tend to be higher in Slovenia than in the other countries being researched. Slovenia was the first of these countries to join the EU, benefit from EU accession funds, and a higher utilization of the flows. In addition, the Ljubljana Stock Exchange (LJSE), Slovenia's only stock exchange, was owned by the Vienna Stock Exchange for a signifcant period. In the case of Slovenia, the MMIR indicator test results are further constrained by use of the European Central Bank's (ECB) key rate for market policies, given that the Slovenian capital market on its own is rather insignificant. This means that during the research period, Slovenia was the first to use the euro, and hence during the research period the ECB key rate was used as an indicator. The empirical testing results for the case of Croatia show the existence of short-run statistically significant relationships in the FX positive coefficient and in the positive HICP indicator coefficient. The FX coefficient results are in alignment with the portfolio theory that an increasing value of the currency is favorable for portfolio investors to rebalance their portfolio positions in a more valuable currency (Ajayi \& Mougoue, 1996; Lin, 2012; Chkili \& Nguyen, 2014; Lee \& Wang, 2015).

Even so, a positive FX coefficient contradicts the traditional theory that an increase in the value of a local currency hurts exports and the flow-on effect on the performance of the stock prices of export-dependent companies. These results are not surprising when taking into account that the Croatian economy is largely import dependent and runs a trade deficit. Overall, the limited impact of U.S. dollars, as the FX indicator currency pair, on the Croatian economy must be kept in focus when interpreting the importance of the test results of the FX coefficient. The result of the HICP indicator's short-run relationship estimating coefficient for Croatia is rather market specific and requires more extensive local risk analysis.

The test results of this empirical study show that the results of the unstable longrun relationships of the individual countries, such as B\&H and Serbia, imply that there is a statistically significant negative coefficient in the short-run associating relationship for the HICP indicator. The short-run negative coefficient result is identical to the HICP long-run relationship coefficient and is in alignment with theoretical expectations (Azar, 2010; Balduzzi, 1994; Campbell \& Vuolteenaho, 2004). In Serbia, the MMIR indicator is statistically significant and negative in the short run, which remains in alignment with the long-run relationship coefficient. Moreover, in the case of Serbia, the results imply statistical significance by the GDPPC indicator for the first time, although the estimating association coefficient is minor. This result draws comparisons to research claiming that in poorer markets with lower stock exchange capitalization and liquidity, the GDPPC indicator exhibits a greater correlation of the macroeconomic indicators to a systemic movement in stock prices (Morck, Yeung, $\& \mathrm{Yu}, 2000)$. However, the respective statistical indicators for Serbia show that of the research countries in Southeast Europe it has the second weakest capitalization and liquidity, but a median GDPPC level. 


\section{Conclusions}

This research paper empirically demonstrates that there is a statistically significant relationship between macroeconomic indicators and stock prices. The results reaffirm that the capital markets in Southeast Europe are weak form information inefficient. The results of the aggregate group data panel PMG for the selected markets demonstrate the nonexistence of an estimated impact of the statistically significant short-run individual macroeconomic indicators on the relationship with SMI. The result is in line with older and recent research utilizing panel PMG in three Asian countries (Megaravalli \& Sampagnaro, 2018).

The results of the empirical research test on the existence of statistically significant long-run cointegrating relationships show an associating negative impact from an increase in the MMIR and HICP macroeconomic indicators on the value of the SMI. Such results also are in line with previous research (Azar, 2010; Balduzzi, 1994; Campbell \& Vuolteenaho, 2004). The existence of a significant long-run relationship association versus the nonexistence of a short-run significant association contradicts the expected performance of a decreasing long-run coefficient impact because of the implementation of control factors such as policy adjustments and a shift in investor sentiment.

Moreover, the nonexistence of significant short-run relationships raises questions about the prevalence of portfolio investors as the ones who are more likely to be sensitive to short-run deviations because of their strategy of having a more imminent response to change events by rebalancing the positions of their investments. The multivariate and cointegrating test results of the aggregate panel PMG in this study dispel implications on the relationship with the GDPPC indicator. What is more, the results of the aggregate panel PMG also discard the existence of a long-run relationship with the FX and IPI indicators, a contradiction with former findings (Binswanger, 2001; Domian and Louton, 1997; Ajayi \& Mougoue, 1996; Lin, 2012; Chkili \& Nguyen, 2014) that may be market specific because of the lesser relevance of U.S. dollars on the economies of Southeast Europe, the prevalence of U.S. dollar-sensitive investors, or the representative importance of the industrial production sector on the overall capital markets and economies.

The results of this empirical research uncover new information that improves the prospects of academics, investors, policymakers, and others to understand and use it to support diversity and sustainability in financial intermediation. The results of the sensitivity testing show that individual countries likely have spurious relationships, which points to a diffusing model robustness and consistencies in the environment that are underpinned by the fundamental structure of the Southeastern European capital markets: lower capitalization, liquidity, a lack of infrastructure, weak intermediation in market making, and higher inherent costs and risks when compared with the benchmarks in the capital markets of advanced countries. The weaknesses 
in the Southeastern European capital markets also are evident in the lack of investor confidence because of subpar investor protection and transparency.

Looking forward, it would be important in future studies to incorporate and endogenize additional qualitative factors such as event studies and governance indicators in the development nexus for the capital markets of Southeast Europe. It would also be important to repeat studies on the impact of structural reforms on other Southeastern European countries, do panel multivariate model testing of the relationships under the reverse direction order, incorporate a more extensive data set for longer periods of time, and update the tests on the chosen time intervals and statistical methodologies.

\section{Appendix}

Main Text Tables and Figures

Appendix Table 1: Summary of the Literature on the Nexus Relationships

\begin{tabular}{|c|c|c|c|c|c|}
\hline \multicolumn{2}{|c|}{ Author } & $\begin{array}{l}\text { Method or } \\
\text { Approach }\end{array}$ & $\begin{array}{c}\text { Sample } \\
\text { Countries }\end{array}$ & $\begin{array}{l}\text { Time } \\
\text { Period }\end{array}$ & Findings \\
\hline \multicolumn{6}{|l|}{ Developed markets: } \\
\hline \multirow[t]{3}{*}{$\begin{array}{l}\text { Financial sector } \\
<-> \\
\text { Economic growth } \\
\text { nexus }\end{array}$} & $\begin{array}{l}\text { King and Levine } \\
\text { (1993) }\end{array}$ & Correlation & 77 countries & 1960-1989 & $\begin{array}{l}\text { Positive correlation between fi- } \\
\text { nancial market depth indicator, } \\
\text { measured as M3 liquid liabilities } \\
\text { to GDP, to stronger economic } \\
\text { output growth. }\end{array}$ \\
\hline & $\begin{array}{l}\text { Samargandi, } \\
\text { Fidrmuc, Ghosh } \\
\text { (2014) }\end{array}$ & $\begin{array}{l}\text { Panel PMG } \\
\text { estimation }\end{array}$ & $\begin{array}{l}\text { Global sample } \\
\text { of middle- } \\
\text { income } \\
\text { countries }\end{array}$ & $1998-2008$ & $\begin{array}{l}\text { Research utilizes the M3 liquid } \\
\text { liabilities to GDP indicator to } \\
\text { then show the short-run non-sig- } \\
\text { nificance but the long-run signif- } \\
\text { icance of financial development } \\
\text { on economic growth. }\end{array}$ \\
\hline & $\begin{array}{l}\text { Levine and } \\
\text { Zervos (1998) }\end{array}$ & $\begin{array}{l}\text { VAR and OLS } \\
\text { estimations }\end{array}$ & 42 countries & 1976-1999 & $\begin{array}{l}\text { Research captures explanatory } \\
\text { capital markets development in- } \\
\text { dicators, capitalization to GDP } \\
\text { size, turnover values, and turn- } \\
\text { over to capitalization and GDP } \\
\text { ratios. Results prove a significant } \\
\text { and positive relationship between } \\
\text { capital markets development in- } \\
\text { dicators and aggregate economic } \\
\text { output growth. }\end{array}$ \\
\hline
\end{tabular}




\begin{tabular}{|c|c|c|c|c|c|}
\hline \multicolumn{2}{|c|}{ Author } & $\begin{array}{l}\text { Method or } \\
\text { Approach }\end{array}$ & $\begin{array}{c}\text { Sample } \\
\text { Countries }\end{array}$ & $\begin{array}{l}\text { Time } \\
\text { Period }\end{array}$ & Findings \\
\hline \multirow[t]{3}{*}{$\begin{array}{l}\text { Macroeconomic } \\
\text { indicators } \\
<-> \\
\text { Capital markets } \\
\text { prices nexus }\end{array}$} & Fama (1990) & Autoregression & NYSE & 1953-1987 & $\begin{array}{l}\text { Statistically significant relation- } \\
\text { ship between industrial produc- } \\
\text { tion, capital expenditure, gross } \\
\text { national product, and expected } \\
\text { future output to exchange traded } \\
\text { equity returns. }\end{array}$ \\
\hline & $\begin{array}{l}\text { Dumas, Harvey, } \\
\text { and Ruiz (2003) }\end{array}$ & $\begin{array}{l}\text { Correlation, } \\
\text { GMM estimation }\end{array}$ & $\begin{array}{l}12 \text { OECD } \\
\text { countries }\end{array}$ & $1970-1996$ & $\begin{array}{l}\text { Statistically significant posi- } \\
\text { tive relationship between GDP } \\
\text { growth rates and equity returns. }\end{array}$ \\
\hline & $\begin{array}{l}\text { Flannery, } \\
\text { Protopapadakis } \\
(2002)\end{array}$ & ARIMA & Greece & $1980-1996$ & $\begin{array}{l}\text { In this non-linear research efficient } \\
\text { capital market event hypothesis } \\
\text { and second-level relationship are } \\
\text { observed. Results prove significant } \\
\text { negative exchange traded stocks } \\
\text { prices relationship with the infla- } \\
\text { tion, producer price index, and } \\
\text { M1 liabilities macroeconomic in- } \\
\text { dicators. }\end{array}$ \\
\hline \multicolumn{6}{|l|}{ Developing markets: } \\
\hline \multirow[t]{2}{*}{$\begin{array}{l}\text { Financial sector } \\
<-> \\
\text { Economic growth } \\
\text { nexus }\end{array}$} & Koivu (2002) & FE estimation & $\begin{array}{l}\text { Almost all } \\
\text { CEE and CIS } \\
\text { countries }\end{array}$ & $1993-2000$ & $\begin{array}{l}\text { One financial development } \\
\text { proxy, interest rate margin, } \\
\text { streams significant negative } \\
\text { association with economic } \\
\text { growth. In other words, a more } \\
\text { efficient, lower risk, and devel- } \\
\text { oped banking sector improves } \\
\text { the financial market and spurs } \\
\text { economic growth. However, the } \\
\text { credit volume indicator shows } \\
\text { that growth in bank credit does } \\
\text { not speed up economic growth. } \\
\text { The author based her opinion on } \\
\text { the unsustainable credit growth } \\
\text { and soft constraints of sample } \\
\text { specifics observed in transitional } \\
\text { economies together with buffers, } \\
\text { such as a soft controlled budget } \\
\text { or lower banking sector compet- } \\
\text { itiveness. }\end{array}$ \\
\hline & $\begin{array}{l}\text { Cojocaru, } \\
\text { Falaris, } \\
\text { Hoffman, Miller } \\
(2015)\end{array}$ & $\begin{array}{l}\text { First-differenced } \\
\text { GMM estimation }\end{array}$ & $\begin{array}{l}15 \mathrm{CEE} \\
\text { and } 10 \mathrm{CIS} \\
\text { countries. }\end{array}$ & $1990-2008$ & $\begin{array}{l}\text { Results pointed to significant } \\
\text { positive relationship between fi- } \\
\text { nancial sector development and } \\
\text { economic growth, measured as } \\
\text { GDP per capita. Financial sector } \\
\text { development is measured by size } \\
\text { (set as private credit and liquid } \\
\text { liabilities size) and efficiency (set } \\
\text { as interest rate spread, overhead } \\
\text { costs, and bank concentration). }\end{array}$ \\
\hline
\end{tabular}




\begin{tabular}{|c|c|c|c|c|c|}
\hline \multicolumn{2}{|c|}{ Author } & \multirow{2}{*}{$\begin{array}{l}\begin{array}{r}\text { Method or } \\
\text { Approach }\end{array} \\
\text { Granger } \\
\text { causality, } \\
\text { Johansen } \\
\text { cointegration }\end{array}$} & \multirow{2}{*}{$\begin{array}{c}\begin{array}{c}\text { Sample } \\
\text { Countries }\end{array} \\
\text { Turkey }\end{array}$} & \multirow{2}{*}{\begin{tabular}{|c|c}
$\begin{array}{c}\text { Time } \\
\text { Period }\end{array}$ \\
$1990-2001$
\end{tabular}} & \multirow[b]{2}{*}{$\begin{array}{l}\text { Findings } \\
\text { Research tested for relationship } \\
\text { of macroeconomic indicators } \\
\text { of money supply, local currency } \\
\text { exchange rate with U.S. dollars, } \\
\text { trade balance position, and IPI } \\
\text { with exchange traded stocks re- } \\
\text { turns. Results pointed to statis- } \\
\text { tical significance where stocks } \\
\text { return were leading indicators } \\
\text { for macroeconomic proxy money } \\
\text { supply, but the reciprocal was not } \\
\text { true for any of the selected mac- } \\
\text { roeconomic indicators. }\end{array}$} \\
\hline $\begin{array}{l}\text { Macroeconomic } \\
\text { indicators } \\
<-> \\
\text { Capital markets } \\
\text { prices } \\
\text { Nexus }\end{array}$ & $\begin{array}{l}\text { Karamustafa } \\
\text { and Kucukkale } \\
\text { (2003) }\end{array}$ & & & & \\
\hline & Pilinkus (2010) & $\begin{array}{l}\text { Granger } \\
\text { causality, } \\
\text { Johansen } \\
\text { cointegration, } \\
\text { panel VAR }\end{array}$ & $\begin{array}{l}\text { Lithuania, } \\
\text { Latvia, and } \\
\text { Estonia }\end{array}$ & $2000-2008$ & $\begin{array}{l}\text { Macroeconomic indicators yield- } \\
\text { ed roughly } 40 \text { percent explanato- } \\
\text { ry power on stock markets in- } \\
\text { dexes fluctuations. Individually, } \\
\text { from the } 10 \text { comparable macro- } \\
\text { economic indicators used in the } \\
\text { long run, almost all were signifi- } \\
\text { cantly related to exchange trad- } \\
\text { ed indexes, yet in the short run, } \\
\text { GDP proved insignificant for all } \\
\text { indexes. In the short run, HICP } \\
\text { (lagged by one period), and } \\
\text { short-term interest rates (lagged } \\
\text { by one and two periods) proved } \\
\text { significant solely for the case of } \\
\text { the Latvian stock market index. }\end{array}$ \\
\hline & $\begin{array}{l}\text { Megaravalli and } \\
\text { Sampagnaro } \\
\text { (2018) }\end{array}$ & $\begin{array}{l}\text { Granger } \\
\text { causality, } \\
\text { Johansen } \\
\text { cointegration, } \\
\text { panel PMG } \\
\text { estimation }\end{array}$ & $\begin{array}{l}\text { India, China, } \\
\text { Japan }\end{array}$ & 2008-2016 & $\begin{array}{l}\text { Research examined the long-and } \\
\text { short-run relationship between } \\
\text { exchange traded markets returns } \\
\text { and macroeconomic variables of } \\
\text { foreign exchange rate and infla- } \\
\text { tion. The results showed signif- } \\
\text { icant cointegration in all rela- } \\
\text { tionships, bidirectional causality } \\
\text { with FX, and unidirectional cau- } \\
\text { sality with inflation. More so, the } \\
\text { PMG test showed a statistically } \\
\text { significant FX positive long-run } \\
\text { relationship with stock returns. }\end{array}$ \\
\hline
\end{tabular}




\begin{tabular}{|c|c|c|c|c|c|}
\hline \multicolumn{2}{|c|}{ Author } & $\begin{array}{l}\text { Method or } \\
\text { Approach }\end{array}$ & $\begin{array}{c}\text { Sample } \\
\text { Countries }\end{array}$ & $\begin{array}{l}\text { Time } \\
\text { Period }\end{array}$ & Findings \\
\hline \multicolumn{6}{|c|}{ Southeastern European markets: } \\
\hline \multirow[t]{2}{*}{$\begin{array}{l}\text { Financial sector } \\
<-> \\
\text { Economic growth } \\
\text { nexus }\end{array}$} & $\begin{array}{l}\text { Haiss and Vukcic } \\
(2005)\end{array}$ & $\begin{array}{l}\text { Panel FE } \\
\text { estimation }\end{array}$ & $\begin{array}{l}27 \mathrm{CEE} \\
\text { countries }\end{array}$ & $1996-2000$ & $\begin{array}{l}\text { Financial intermediation in do- } \\
\text { mestic credit and bonds signifi- } \\
\text { cantly contributed to economic } \\
\text { growth statistically, but at the } \\
\text { same time the private credit and } \\
\text { the stock markets had no sig- } \\
\text { nificant effect on the economic } \\
\text { growth. }\end{array}$ \\
\hline & $\begin{array}{l}\text { Lazarov, Miteva- } \\
\text { Kacarski, } \\
\text { Nikoloski (2016) }\end{array}$ & GMM estimation & $\begin{array}{l}10 \\
\text { Southeastern } \\
\text { European } \\
\text { and } 4 \text { CEE } \\
\text { countries }\end{array}$ & 2002-2012 & $\begin{array}{l}\text { Results showed a statistically } \\
\text { significant positive association } \\
\text { between capital market develop- } \\
\text { ment and economic growth, as } \\
\text { measured by the GDP per capita } \\
\text { indicator. Capital market devel- } \\
\text { opment was tracked by the depth } \\
\text { in capitalization, the turnover } \\
\text { ratio, and stock price volatility. } \\
\text { This research conducted a total } \\
\text { of } 20 \text { observations. }\end{array}$ \\
\hline \multirow[t]{2}{*}{$\begin{array}{l}\text { Macroeconomic } \\
\text { indicators } \\
<-> \\
\text { Capital markets } \\
\text { prices } \\
\text { Nexus }\end{array}$} & $\begin{array}{l}\text { Drazenovic, } \\
\text { Kusanovic (2016) }\end{array}$ & $\begin{array}{l}\text { FE and RE } \\
\text { estimations }\end{array}$ & $\begin{array}{l}\text { Croatia, } \\
\text { Czech } \\
\text { Republic, } \\
\text { Hungary, } \\
\text { Poland, Slova } \\
\text { Republic, and } \\
\text { Slovenia }\end{array}$ & $1995-2010$ & $\begin{array}{l}\text { The statistically significant fac- } \\
\text { tors on the size of inherent cap- } \\
\text { ital markets were the impact of } \\
\text { size of investment funds, life in- } \\
\text { surance premiums, and inflation. } \\
\text { Other factors that proved insig- } \\
\text { nificant were the size of pension } \\
\text { funds, the EBRD indicator of the } \\
\text { level of large-scale privatization, } \\
\text { the EBRD indicator of the level } \\
\text { of reform of banks and finan- } \\
\text { cial institutions, inflation, gross } \\
\text { savings, and the nominal GDP } \\
\text { growth rate. }\end{array}$ \\
\hline & $\begin{array}{l}\text { Barbic, Condic- } \\
\text { Jurkic (2011) }\end{array}$ & $\begin{array}{l}\text { Granger } \\
\text { causality, } \\
\text { Johansen } \\
\text { cointegration }\end{array}$ & $\begin{array}{l}\text { Croatia, } \\
\text { Czech } \\
\text { Republic, } \\
\text { Hungary, } \\
\text { Poland, and } \\
\text { Slovenia }\end{array}$ & $1998-2010$ & $\begin{array}{l}\text { Results pointed to the existence } \\
\text { of a statistically significant } \\
\text { long-run bivariate cointegrating } \\
\text { relationship, but no causality be- } \\
\text { tween stock markets and the se- } \\
\text { lected macroeconomic variables } \\
\text { of the inflation rate, money mar- } \\
\text { ket interest rates, money supply, } \\
\text { and foreign exchange reserves in } \\
\text { the individual cases of Croatia, } \\
\text { Hungary, and Poland. }\end{array}$ \\
\hline
\end{tabular}




\section{A Structural Preview of the Capital Markets in Southeast Europe}

\section{Appendix Figure 1: Croatia's Capital Market}

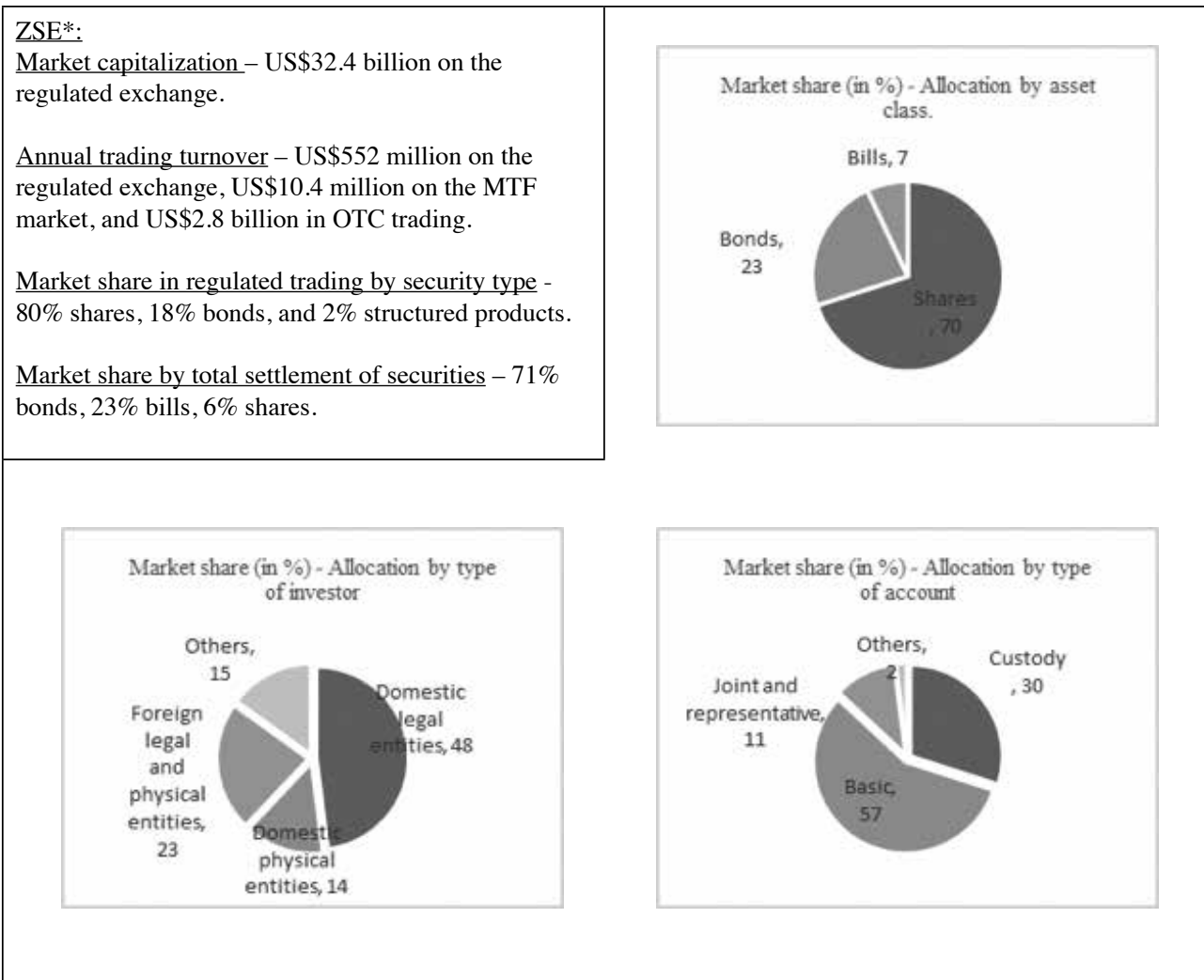

*Year-end 2016 data sourced from the Zagreb Stock Exchange (2017) and March 31, 2018 data sourced from the Central Depositary and Clearing Company Inc. (2018). 


\section{Appendix Figure 2: Slovenia's Capital Market}

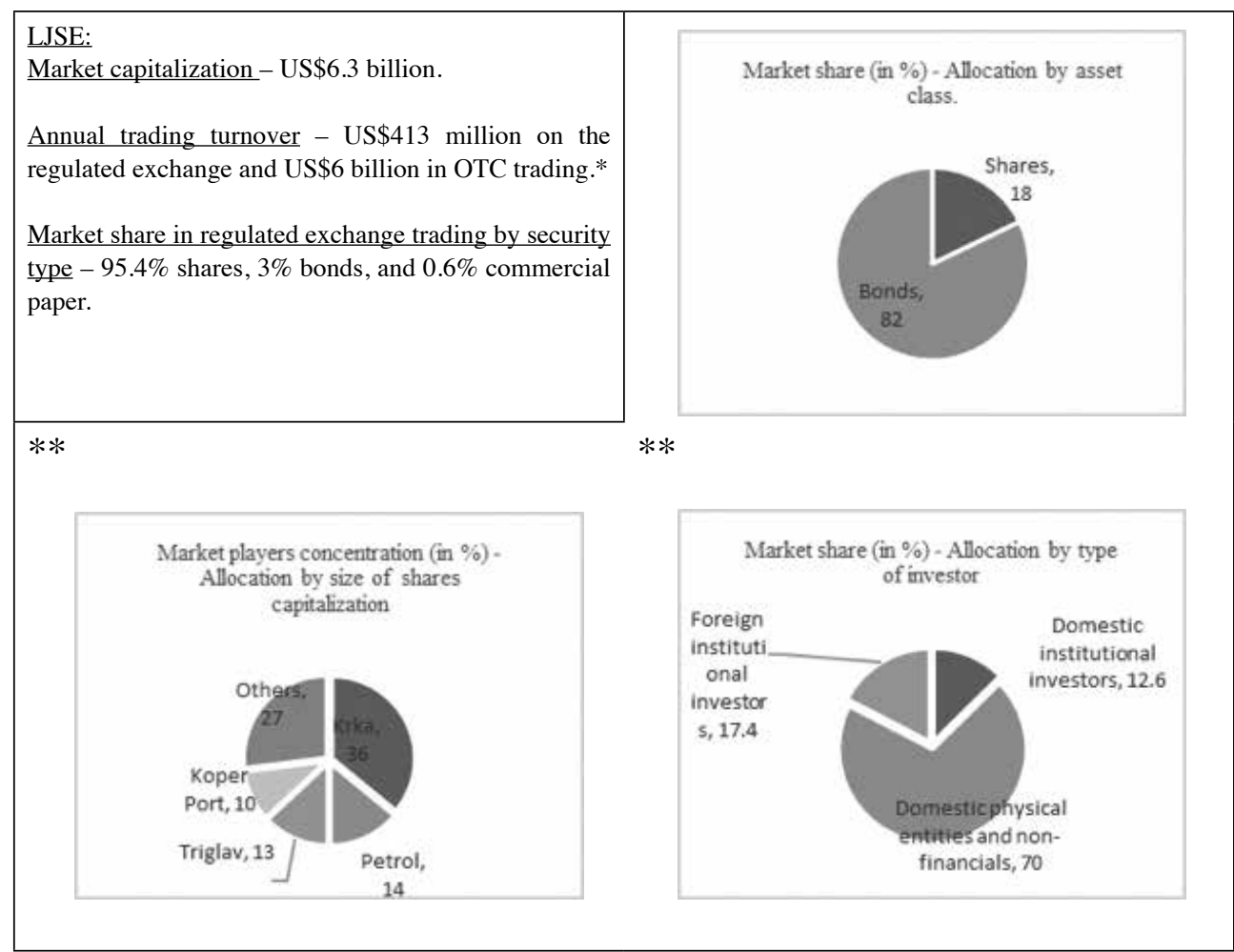

*Year-end 2017 data sourced from the Ljubljanska Stock Exchange (2017) and KDD Centralna Klirinsko Depotna Druzba d.d. Ljubljana (2017).

** Data as per LJSE regulated market.

*** Multilateral trading facility (MTF) capitalization and trading data is not publicly available. 


\section{Appendix Figure 3: B\&H's Capital Market}

Market capitalization**_-

SASE at US\$3.1 billion.

BLSE at US $\$ 2.5$ billion.

Annual trading turnover**-

Federation of Bosnia and Herzegovina $(\mathrm{FB} \& \mathrm{H})$ at US\$83 million in ordinary trading and at US\$217 million in primary issues, auctions, and block trading.

BLSE at US\$36.4 million in ordinary trading and US\$261.8 million in primary issues, auctions, and block trading.

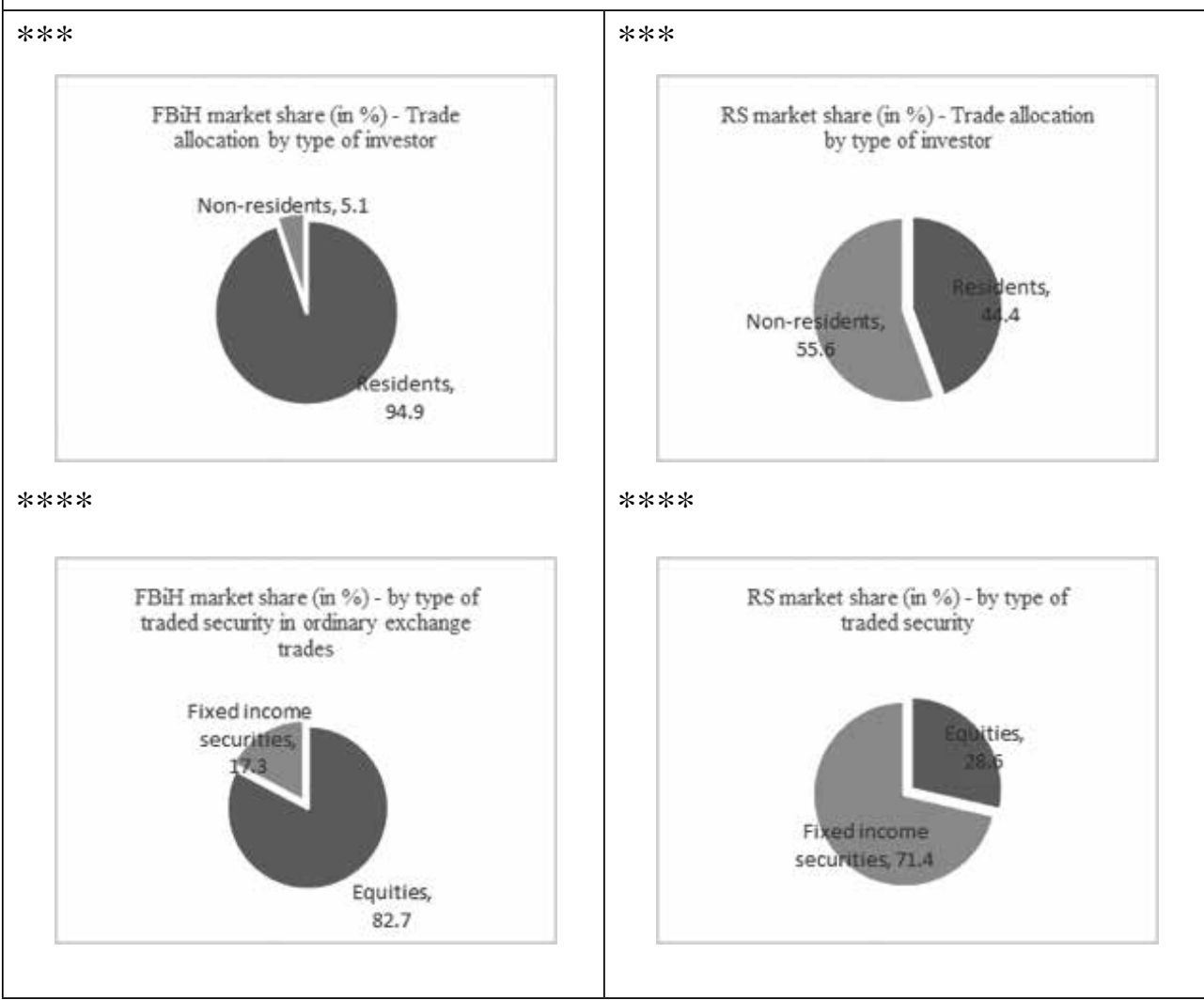

*MTF and OTC data is not available.

**Year-end 2017 data sourced from the Banja Luka Stock Exchange (2018) and Sarajevo Stock Exchange (2018).

*** Year-end 2017 data sourced from the Securities Commission Banja Luka Stock Exchange (2018) and Registry of Securities of Federation of Bosnia and Herzegovina (2018).

****Excludes data on primary issues, auctions, and block trades. 


\section{Appendix Figure 4: Serbia’s Capital Market}

Market capitalization - US $\$ 2.7$ billion.

Annual trading turnover -US $\$ 369.2$ million on the regulated exchange, US\$12.6 million on MTF, and US\$28.1 billion in OTC trading.**

Market share in organized exchange trading by security type $-89.9 \%$ bonds and $11.1 \%$ shares.*

Market share by type of investor $-13 \%$ physical entities, $80 \%$ legal entities, $7 \%$ other.*

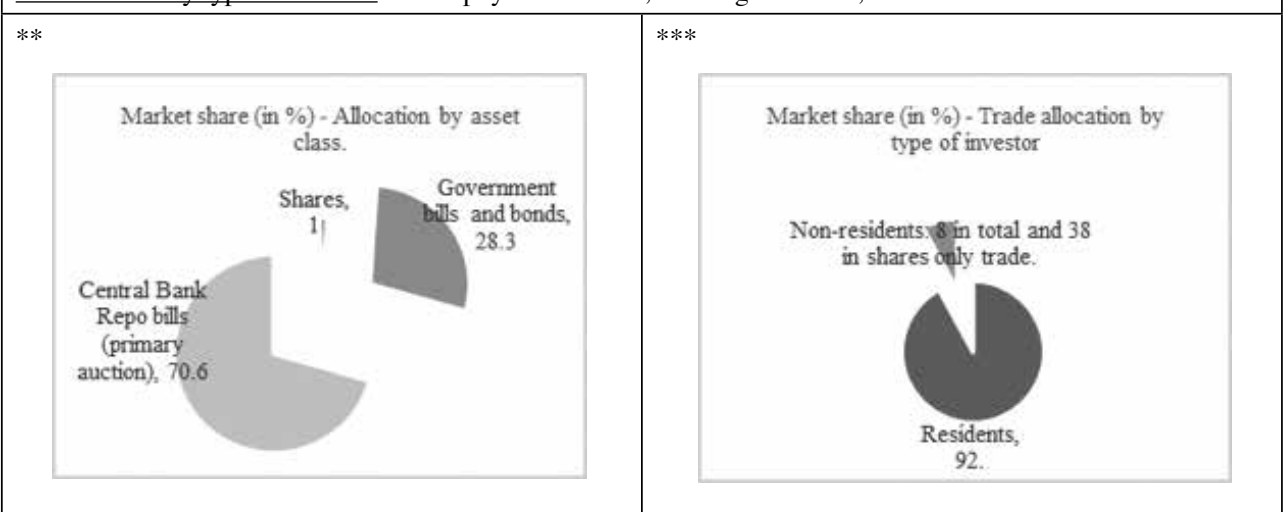

*Data sourced from the Belgrade Stock Exchange (2018).

**Year-end 2017 OTC data is unavailable and thus the research uses year-end 2016 annual report data from Republic of Serbia Securities Commission (2017). The majority of the recorded OTC transactions involves central bank repo transactions and primary sales transactions.

***According to the Central Depository specifications on clients. 
Appendix Figure 5: North Macedonia's Capital Market

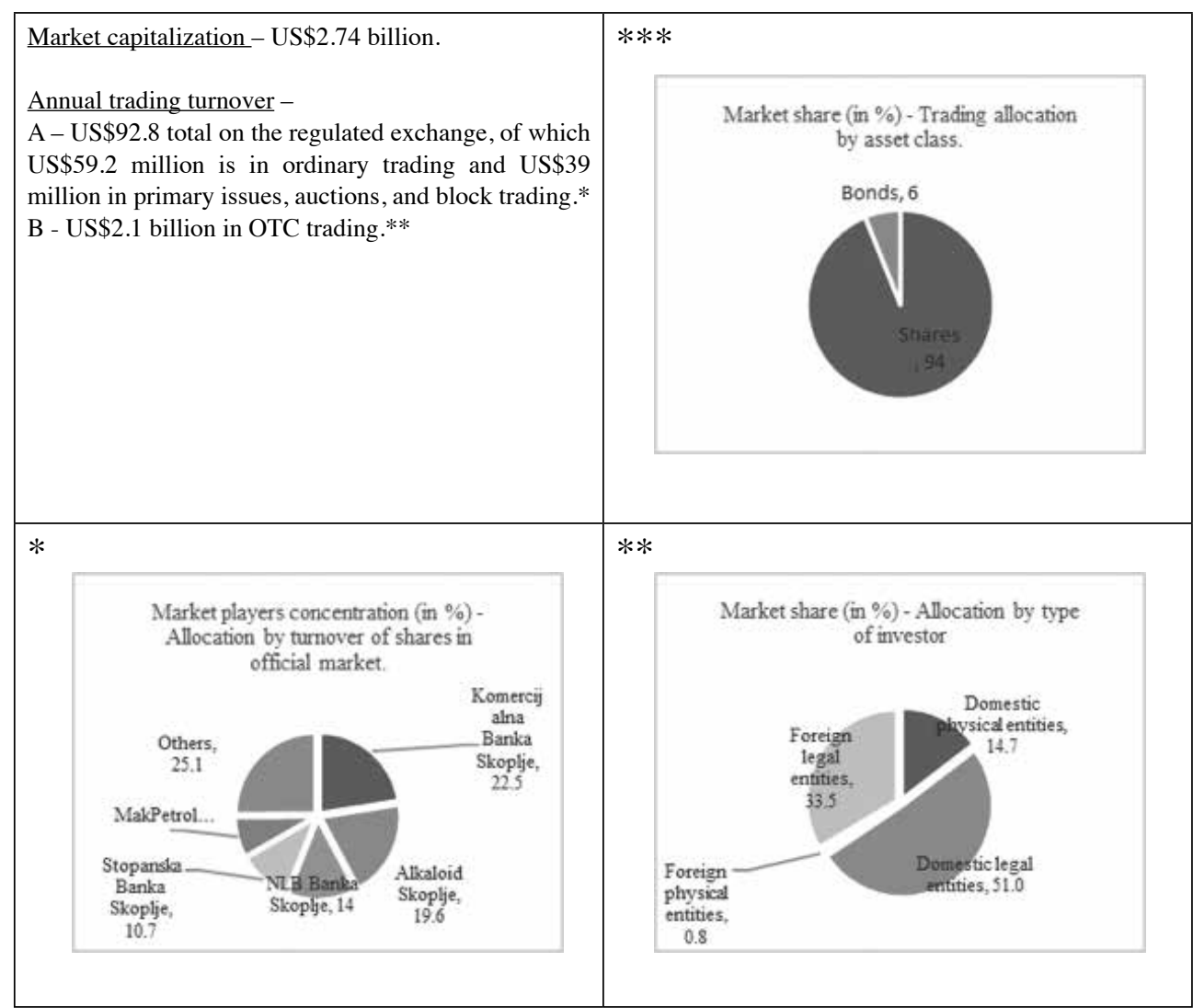

*Year-end 2017 values. Data sourced from the Macedonian Stock Exchange (2017).

***Data sourced from year-end 2016 Annual Report, Central Securities Depository of the Republic of Macedonia (2017)

***Regulated trading only and excludes block trades, primary issues, auctions, and OTC transactions.

****MTF market is not available.

\section{Data Sources, Limitations, and Descriptive Statistics}

\section{Sources}

This empirical research assessment captures primary and secondary data sourced from reputable private and public institutions. Stock exchange performance is measured through indicative market end of day price indexes sourced exclusively from Bloomberg (2018), a privately held financial software, data, and media company 
headquartered in New York City, United States of America. Data are collected from the Bloomberg Terminal service. Data on the BATX index, in Bosnia and Herzegovina convertible marks (BAM), are sourced directly from the historical data on the website of the Vienna Stock Exchange (2018). The data on legislative, regulatory, and market dynamics are collected from primary sources including the law companies, investment brokers, fund managers, and commercial banks operating in the inherent capital markets.

The macroeconomic indicators are collected from a more diverse source base and in the following order:

1- Eurostat (2018), European Commission Directorate-General for harmonized statistical data, for data on:

i. Industrial production index (utilizing NACE Rev.2 methodology which includes sections on manufacturing, mining and quarrying, and electricity, gas, steam, and air conditioning supply at prices index of $2010=100$ );

ii. HICP data with the exception of B\&H and North Macedonia (collected data are on an unadjusted basis with year-end $2015=100$ base unit then manually re-referenced to year-end $2010=100$ ). HICP data follow the European Classification of Individual Consumption by Purpose (ECOICOP) methodology;

iii. Balance of payments net financial account data for Croatia and Slovenia;

iv. GDP data for North Macedonia (under expenditure approach and ESA 2010 methodology).

2- Central bank data for:

i. Currency exchange rate data (per end of day mid-rate);

ii. Key interest rates. The European Central Bank (2018) is the source for Slovenia and B\&H. The National Bank of Croatia (2018) (HNB) provides the key discount rate. The National Bank of Serbia (2018) (NBS) provides the key discount rate prior to September 2006 and the key interest rate thereafter. The National Bank of Macedonia (2018) (NBRM) provides the key interest rate, and this research uses the key refinancing rate from ECB.

iii. The Central Bank of Bosnia and Herzegovina (2018) (CBB\&H), NBS, and NBRM provide data on the BOPNFA results for B\&H, Serbia, and North Macedonia, respectively.

3- The national statistics agencies - the Croatian Bureau of Statistics (2018), Statistical Office of the Republic of Serbia (2018), Republic of Macedonia State Statistical Office (2018), Statistical Office of the Republic of Slovenia (2018), and Agency for Statistics for Bosnia and Herzegovina (2018) (BHAS) - are the sources for data on:

i. Population as per the most recent census. The North Macedonia census was in 2002, and the Slovenia and Serbia censuses were in 2002 and 2011, respectively. The census in B\&H was conducted in 1991 and 2013, and in Croatia in 2001 and 2011. 
ii. The consumer purchasing index (CPI) in case of $\mathrm{B} \& \mathrm{H}$ (referenced for year-end $2010=100$ base unit because year-end $2015=100$ is not available) and North Macedonia (referenced for average year-end $2010=100$ base unit as year-end 2015=100 is not available). For North Macedonia and B\&H, the CPI index follows the classification of individual consumption by purpose (COICOP) methodology.

iii. GDP in case of B\&H, Slovenia, Croatia, and Serbia (under expenditure approach and ESA year 2010 methodology).

\section{Limitations}

In the case of $\mathrm{B} \& \mathrm{H}$, it was not possible to use independent variables at the entity level, such as for the BOPNFA indicator, and overall by using equal independent variables on two different dependent variables, the BIRS (the blue-chip companies on the Banja Luka Stock Exchange) and SASX-10 (the blue-chips on the Sarajevo Stock Exchange) indexes, we would create endogeneity between the set variables. As a solution, this research uses a single country index, the BATX (Bosnian Traded Index), even though it was established later than the others, in December 2009. This choice accomplishes better reliability and consistency with the comparable single country indexes and the overall data testing. The BATX index was introduced in December 2009 and thus the research does not capture index values for $\mathrm{B} \& \mathrm{H}$ for the 16 quarterly periods starting with initial value from the end of 2005 . Because of this and all other data limitations, original data information is in use and without converging to manually create and populate the missing entries that could distort the business environment structure impact interpretation. For the same reason, the research neither creates a weighted joint index between the BIRS and SASX-10 indexes for the missing periods, and for this research it is important to note to readers the results limitations stemming from 1) data constraints, 2) methodologies boundaries, and 3) impact of the specific intertwined and gray economy overshadowed operating business environment. For future research and with the availability of a lengthier set of data, it is recommended to repeat the same statistical tests in this study.

In the cases of B\&H and Slovenia, this research uses euro area macroeconomic indicators for key interest rates in proxy of money market interest rate and for foreign exchange rate data. B\&H does not run its own monetary policy and the currency is fixed to the euro. Slovenia, on the other hand, joined the euro area starting in 2007. In the case of Slovenia, for year-end 2005 and for all periods in 2006, this research does not use key reference rate and exchange rate data in order to maintain consistency and harmonization with euro data for other years. In the case of Slovenia, the SBITOP index was introduced in April 2006 and thus this research does not use the index value for two time periods: year-end 2005 and the end of the first quarter of 2006. 
For B\&H and Serbia, the results of the balance of payments net financial account are not available for year-end 2005 and full year 2006 under otherwise IMF 6th methodology.

For the specific case of B\&H, GDP data, calculated in expenditure approach, are not available for the periods starting at year-end 2005 through the ends of the following quarters until and including year-end 2007. The National Statistics Office has responded to the research enquiry on the data, but did not indicate if thess data will be further available at a later stage.

B\&H and North Macedonia do not calculate inflation with the HICP approach, and this research uses the local CPI indicator, which is only available in reference of year-end $2010=100$ base unit, or year-end $2005=100$ base unit for B\&H for year-end 2005 to year-end 2010. Therefore, to achieve consistency in this research, data are manually re-referenced for HICP and CPI data to year-end 2010=100 base unit. For $\mathrm{B} \& \mathrm{H}$, the CPI indicator is not available on quarter-end dates, other than for year-end value, for the period from beginning in year 2006 through end of year 2010.

For B\&H and the time period for year-end 2005, the IPI indicator value was unavailable.

Appendix Table 2: Group Data - Descriptive Statistics

\begin{tabular}{|l|c|c|r|r|r|r|r|r|r|}
\hline Variable & Years & Observations & Mean & Median & Max & Min & St. Dev. & Skewness & Kurtosis \\
\hline SMI & $2005-2016$ & 207 & 1638.85 & 1451.32 & 9283 & 380 & 1323.53 & 2.53 & 8.85 \\
\hline GDPPC & $2005-2016$ & 216 & 2067.36 & 1170.45 & 5071.32 & 588.42 & 1429.99 & 0.9 & -0.71 \\
\hline $\boldsymbol{F X}$ & $2005-2016$ & 220 & 0.4176 & 0.1747 & 1.5622 & 0.0087 & 0.4899 & 0.9594 & -0.5174 \\
\hline MMIR & $2005-2016$ & 215 & 0.0525 & 0.0425 & 0.18 & 0 & 0.041 & 0.594 & -0.1759 \\
\hline HICP & $2005-2016$ & 210 & 101.5 & 103.19 & 129.9 & 66.93 & 11.59 & -0.13 & 1.13 \\
\hline IPI & $2005-2016$ & 224 & 105.87 & 106.15 & 133 & 81 & 9.12 & 0.07 & 0 \\
\hline BOPNFA & $2005-2016$ & 215 & -319.55 & -255.7 & 2637.5 & -2262.3 & 653.94 & 0.4894 & 3.752 \\
\hline
\end{tabular}

\section{REFERENCES}

Agency for Statistics for Bosnia and Herzegovina. (2018). Retrieved on May 1, 2018, from http://www. bhas.ba/index.php?lang=en

Ajayi, R., \& Mougoue, M. (1996). On the dynamic relations between stock prices and exchange rates. Journal of Financial Research. DOI: doi.org/10.1111/j.1475-6803.1996.tb00593.x

Alfaro, L., Chanda, A., Kalemli-Ozcan, S., \& Sayek, S. (2004). FDI and economic growth: the role of local financial markets. Journal of International Economics. DOI: 10.1016/S00221996(03)00081-3

Alrub, A. A., Tursoy, T., \& Rjoub, H. (2016). Exploring the Long-run and Short-run Relationship between Macroeconomic Variables and Stock Prices during the Restructuring Period: Does it Matter in Turkish Market? IBIMA Journal of Financial Studies \& Research. DOI: $10.5171 / 2016.917071$ 
Azar, S. A. (2010). Inflation and stock returns. International Journal of Accounting and Finance.

Balduzzi, P. (1994). Stock Returns, Inflation, and the "Proxy Hypothesis:" A New Look at the Data. New York University - Stern School of Business . DOI: dx.doi.org/10.1016/0165-1765(94)00568-M

Banja Luka Stock Exchange. (2018). Retrieved on May 18, 2018, from https://www.blberza.com/Pages/ docview.aspx?page $=$ sp4

Barbic, T., \& Condic-Jurkic, I. (2011). Relationship between macroeconomic fundamentals and stock market indexes in select CEE countries. Ekonomski Pregled, 113-133.

Belgrade Stock Exchange. (2018). Retrieved on June 05, 2018, from https://www.belex.rs/eng/trgovanje/izvestaj/godisnji

Binswanger, M. (1999). Stock market booms and real economic activity: Is this time different? International Review of Economics and Finance. DOI: 10.1016/S1059-0560(99)00056-8

Bloomberg. (2018). Retrieved on October 7, 2018, via proprietary software access.

Campbell, J., \& Vuolteenaho, T. (2004). Inflation Illusion and Stock Prices. National Bureau of Economic Research. DOI: 10.1257/0002828041301533

Central Bank of Bosnia and Herzegovina. (2018). Retrieved on February 22, 2018, from http://statistics. cbbh.ba/Panorama/novaview/SimpleLogin_en_html.aspx

Central Depositary and Clearing Company Inc. (2018). Quarterly report: First quarter 2018. Zagreb.

Central Securities Depository of the Republic of Macedonia. (2017). 2016 Annual Report.

Chkili, W., \& Nguyen, D. (2014). Exchange rate movements and stock market returns in regime-switching environment: Evidence for BRICS countries. IPAG Business School - Working Papers.

Cojocaru, L., Falaris, E. M., Hoffman, S. D., \& Miller, J. B. (2015). Financial System Development and Economic Growth in Transition Economies: New Empirical Evidence from the CEE and CIS Countries. Bankable Frontier Associates, University of Delaware, Gallaudet University. DOI: doi.org/10.1080/1540496X.2015.1013828

Croatian Bureau of Statistics. (2018). Retrieved on May 1, 2018, from https://www.dzs.hr/Eng/system/ starte.htm

Dickey, D. A., \& Fuller, W. A. (1979). Distribution of the Estimators for Autoregressive Time Series with a Unit Root. Journal of the American Statistical Association, 427-431. DOI: 10.2307/2286348

Domian , D., \& Louton, D. (1997). A threshold autoregressive analysis of stock returns and real economic activity. International Review of Economics and Finance. DOI: doi.org/10.1016/ S1059-0560(97)90022-8

Dumas, B., Campbell, H., \& Ruiz, P. (2003). Are correlations of stock returns justified by subsequent changes in national outputs? Journal of International Money and Finance, 777-811. DOI: 10.1016/j.jimonfin.2003.08.005

Erhmann, M., \& Fratzscher, M. (2004). Taking stock: Monetary policy transmission ot equity markets. European Central Bank. DOI: 10.1353/mcb.2004.0063

European Central Bank. (2018). Retrieved on April 1, 2018, from https://sdw.ecb.europa.eu/

Eurostat. (2018). Eurostat databased retrieve on November 3, 2018, from https://ec.europa.eu/eurostat/ data/database

Fama, E. F. (1981). Stock Returns, Real Activity, Inflation and Money. American Economic Review, 545-565.

Fama, E. F. (1990). Stock Returns, Expected Returns, and Real Activity. The Journal of Finance, 10891108. DOI: doi.org/10.1111/j.1540-6261.1990.tb02428.x

Fama, E., \& Malkiel, B. (1970). Efficient Capital Markets: A Review of Theory And Empirical Work. The American Finance Association - The Journal of Finance. DOI: 10.2307/2325486

Fink, G., Haiss, P., \& Vuksic, G. (2005). Importance of Financial Sectors for Growth in Accession Countries. University of Economics and Business Administration - Vienna. DOI: dx.doi. org/10.2139/ssrn.676321 
Flannery, M. J., \& Protopapadakis, A. (2002). Macroeconomic Factors Do Influence Aggregate Stock Returns. The Review of Financial Studies, 751-782. DOI: dx.doi.org/10.2139/ssrn.314261

Issahaku, H., Ustarz, Y., \& Domanban, P. B. (2013). Macroeconomic variables and stock market returns in Ghana: Any causal link? Asian Economic and Financial Review.

Johnson, R., Jensen, G., \& Conover, M. (1999). Monetary environments and international stock returns. Journal of Banking and Finance.

Karamustafa, O., \& Kucukkale, Y. (2003). Long-run relationships between stock market returns and macroeconomic preformance. International Research Journal of Finance and Economics.

KDD Centralna Klirinsko Depotna Druzba d.d. Ljubljana. (2017). Main Figures 2017.

King, R., \& Levine, R. (1993). Finance and growth: Schumpeter might be right. The Quarterly Journal of Economics. DOI: doi.org/10.2307/2118406

Koivu, T. (2002). Do efficient banking sectors accelerate economic growth in transition countries? Bank of Finland - Institute for Economies in Transition, BOFIT, N0.14. DOI: 10.2139/ ssrn. 1015710

Lazarov, D., Miteva-Kacarski, E., \& Nikoloski, K. (2016). An Empirical Analysis of Stock Market Development and Economic Growth: The Case of Macedonia. Southeast European Journal of Economics and Business, 71-81. DOI: 10.1515/jeb-2016-0012

Lee, C.-C., \& Chang, C.-P. (2009). FDI, financial development, and economic growth: International evidence. Journal of Applied Economics. DOI: 10.1016/S1514-0326(09)60015-5

Lee, Y.-M., \& Wang, K.-M. (2015). Dynamic heterogenous panel analysis of the correlation between stock prices and exchange rates. Taylor and Francis. DOI: doi.org/10.1080/133167 7X.2015.1084889

Levine, R., \& Zervos, S. (1998). Stock Markets, Banks, and Growth. American Economic Review, 537-558.

Lin, C.-H. (2012). The comovement between exchange rates and stock prices in the Asian emerging markets. International Review of Economics and Finance. DOI: 10.1016/j.iref.2011.09.006

Ljubljana Stock Exchange. (2017). Ljubljana Stock Exchange Statistics retrieved on April 28, 2018, from www.ljse.si/cgi-bin/jve.cgi?doc=2330.

Macedonian Stock Exchange. (2017). Annual Statistical Report retrieved on May 19, 2018, from http:// www.mse.mk/en/content /22/1/2008/history.

Megaravalli, A. V., \& Sampagnaro, G. (2018). Macroeconomic indicators and their impact on stock markets in ASIAN 3: A pooled mean group approach. Cogent Economics and Finance. DOI: doi.org/10.1080/23322039.2018.1432450

Morck, R., Yeung, B., \& Yu, W. (2000). Why Do Emerging Markets Have Synchronous Stock Price Movements? Journal of Financial Economics. DOI: 10.1016/S0304-405X(00)00071-4

Naceur, S.B., Ghazouani, S., \& Omran, M. (2007). The determinants of stock market development in the Middle Eastern and North African region.Emerald.DOI: doi.org/10.1108/03074350710753753

National Bank of Croatia. (2018). Retrieved on February 22, 2018, from https://www.hnb.hr/en/statistics/statistical-data

National Bank of Finland. (2018). Retrieved on February 22, 2018, from https://www.suomenpankki.fi/ en/financial-stability/the-financial-system-in-brief/

National Bank of Serbia. (2018). Retrieved on February 22, 2018, from https://www.nbs.rs/internet/ english/80/index.html

National Bank of the Republic of Macedonia. (2016). Financial Stability Report for the Republic of Macedonia in 2016.

National Bank of the Republic of Macedonia. (2018). Retrieved on February 22, 2018, from http:// www.nbrm.mk/statistika-en.nspx

National Bank of Slovenia. (2018). Retrieved on February 22, 2018, from https://www.bsi.si/en/statistics 
Registry of Securities of Federation of Bosnia and Herzegovina. (2018). Retreived on March 2, 2018, from http://www.rvp.ba/english/

Republic of Macedonia State Statistical Office. (2018). Retrieved on May 1, 2018, from http://makstat. stat.gov.mk/PXWeb/pxweb/en/MakStat/?rxid=46ee0f64-2992-4b45-a2d9-cb4e5f7ec5ef

Republic of Serbia Securities Commission. (2017). 2016 Annual Report. Belgrade.

Sarajevo Stock Exchange. (2018). Retrieved on May 15, 2018, from http://www.sase.ba/v1/en-us/ SASE/About-SASE/SASE-History

Securities Commission Banja Luka Stock Exchange. (2018). Retrieved on March 1, 2018, from https:// www.crhovrs.org/index.php/en/

Samargandi, N., Fidrmuc, J., \& Ghosh, S. (2014). Is the Relationship between Financial Development and Economic Growth Monotonic? Evidence from a Sample of Middle Income Countries. Ludwig Maximilians Univerity Center for Economic Studies and the Ifo Institute. DOI: 10.1016/j.worlddev.2014.11.010

Shapiro, M. (1988). The Stabilization of the U.S. Economy Evidence From the Stock Market. The National Bureau of Economic Research.

Statistical Office of the Republic of Serbia. (2018). Retrieved on May 1, 2018, from http://www.stat.gov. rs/en-us/o-nama/statisticki-sistem-srbije-1/\#

Statistical Office of the Republic of Slovenia. (2018). Retrieved on May 1, 2018, from https://www.stat. si/statweb/en?Aspx AutoDetectCookieSupport=1 